Article

\title{
Growth and Bioactive Compound Content of Glehnia littoralis Fr. Schmidt ex Miquel Grown under Different $\mathrm{CO}_{2}$ Concentrations and Light Intensities
}

\author{
Hye Ri Lee ${ }^{1}$, Hyeon Min Kim ${ }^{1}$, Hyeon Woo Jeong ${ }^{1}$, Myung Min $\mathrm{Oh}^{2}$ and \\ Seung Jae Hwang 1,3,4,5,* \\ 1 Division of Applied Life Science, Graduate School of Gyeongsang National University, Jinju 52828, Korea; \\ dgpfl77@naver.com (H.R.L.); hmk0766@korea.kr (H.M.K.); J_dk94@naver.com (H.W.J.) \\ 2 Division of Animal, Horticulture and Food Sciences, Chungbuk National University, Cheongju 28644, Korea; \\ moh@cbnu.ac.kr \\ 3 Department of Agricultural Plant Science, College of Agriculture \& Life Science, \\ Gyeongsang National University, Jinju 52828, Korea \\ 4 Institute of Agriculture \& Life Science, Gyeongsang National University, Jinju 52828, Korea \\ 5 Research of Institute of Life Science, Gyeongsang National University, Jinju 52828, Korea \\ * Correspondence: hsj@gnu.ac.kr; Tel.: +82-055-772-1916
}

Received: 8 October 2020; Accepted: 10 November 2020; Published: 15 November 2020

check for updates

\begin{abstract}
This study aims to determine the effect of different $\mathrm{CO}_{2}$ concentrations and light intensities on the growth, photosynthetic rate, and bioactive compound content of Glehnia littoralis Fr. Schmidt ex Miquel in a closed-type plant production system (CPPS). The plants were transplanted into a deep floating technique system with recycling nutrient solution (EC $1.0 \mathrm{dS} \cdot \mathrm{m}^{-1}$ and $\mathrm{pH}$ 6.5) and cultured for 96 days under a temperature of $20 \pm 1^{\circ} \mathrm{C}$, a photoperiod of 12/12 h (light/dark), and RGB LEDs (red:green:blue $=7: 1: 2$ ) in a CPPS. The experimental treatments were set to 500 or $1500 \mu \mathrm{mol} \cdot \mathrm{mol}^{-1}$ $\mathrm{CO}_{2}$ concentrations in combination with one of the three light intensities: 100,200 , or $300 \mu \mathrm{mol} \cdot \mathrm{m}^{-2} \cdot \mathrm{s}^{-1}$ photosynthetic photon flux density (PPFD). The petiole length of G. littoralis was the longest in the $500 \mu \mathrm{mol} \cdot \mathrm{mol}^{-1} \mathrm{CO}_{2}$ concentration with the $100 \mu \mathrm{mol} \cdot \mathrm{m}^{-2} \cdot \mathrm{s}^{-1} \mathrm{PPFD}$. The fresh weight (FW) and dry weight (DW) of shoots and roots were the heaviest in the $300 \mu \mathrm{mol} \cdot \mathrm{m}^{-2} \cdot \mathrm{s}^{-1} \mathrm{PPFD}$ regardless of the $\mathrm{CO}_{2}$ concentration. Higher $\mathrm{CO}_{2}$ concentrations and light intensities produced the greatest photosynthetic rates. However, the SPAD value was not significantly different between the treatments. Higher light intensities produced greater content per biomass of chlorogenic acid and total saponin, although the concentration per DW or FW was not significantly different between treatments. The first and second harvest yields were the greatest in the $300 \mu \mathrm{mol} \cdot \mathrm{m}^{-2} \cdot \mathrm{s}^{-1} \mathrm{PPFD}$, regardless of the $\mathrm{CO}_{2}$ concentration. These results show that the $300 \mu \mathrm{mol} \cdot \mathrm{m}^{-2} \cdot \mathrm{s}^{-1}$ PPFD enhanced the growth, photosynthetic rate, and bioactive compound accumulation of $G$. littoralis, regardless of the $\mathrm{CO}_{2}$ concentration in a CPPS.
\end{abstract}

Keywords: chlorogenic acid; medicinal plant; photosynthetic rate; total saponin

\section{Introduction}

Medicinal plants are those plants where the whole leaves, stems, flowers, fruits, roots, seeds, or whole plants are used as raw materials for medicine. Currently, medicinal plants are being used in various ways as herbal medicines and as the raw materials of cosmetics, functional health foods, and natural medicines; the interest in these products from consumers has increased, thus increasing the demand and related market size [1]. In the Republic of Korea, various medicinal plants are native in the wild because of Korea's geographical characteristics and the four distinct seasons. However, only about 50 kinds of medicinal plants are grown in domestic farms, and there are fewer cultivation 
areas and productions than can supply the increasing demand; therefore, the dependence on imports is also increasing [2]. Because medicinal plants are mainly grown outdoors, the cultivation period is long, the price fluctuation is severe, and the supply of medicinal plants is inelastic. In addition, the harvest time is limited; they are difficult to store or transport; the quality varies between varieties, cultivation environment, and harvest time. Also, the study of the cultivation process for the mass production of medicinal plants (seed germination, growing seedlings, cultivation after transplanting, etc.,) is insufficient, and it is necessary to find suitable conditions for the cultivation environment and develop the optimal cultivation technology for the stable production of high-quality medicinal plants.

Glehania littoralis Fr. Schmidt ex Miquiel is a perennial plant belonging to the Umbelliferae family and is commonly found in coastal dunes. The petiole is long and scarlet, and the leaves are divided into three branches, each having three small leaves, where the small leaves have sawtooth edges, and the young leaves are used as vegetables. It has several functional components, such as saponin, coumarin, bergapten, $\beta$-sitosterol, and imperatorin $[3,4]$, which are known to be effective against sweating, fever, and labor pains, and have diuretic, antiviral, anti-cancer, and immunosuppression properties [5-7].

$\mathrm{CO}_{2}$ is a very important factor in crop cultivation as a raw material for photosynthesis. The maintenance of $\mathrm{CO}_{2}$ concentrations during growth enhances crop growth $[8,9] \cdot \mathrm{CO}_{2}$ enrichment can enhance $\mathrm{CO}_{2}$ fixation, yield, and quality $[10,11]$. Previous results showed that the biomass increased by about $50 \%$ in C3 plants [12], 35\% in CAM (crassulacean acid metabolism) plants [13], and $12 \%$ in C4 plants [14] under $\mathrm{CO}_{2}$ enrichment conditions. Moreover, $\mathrm{CO}_{2}$ enrichment is effective in enhancing vegetable quality by promoting the accumulation of antioxidants in vegetables. Dong et al. [15] showed that $\mathrm{CO}_{2}$ enrichment increased the ascorbic acid, chlorophyll b, total antioxidant activity, total phenols, and total flavonoids by $9.5,42.5,59.0,8.9$, and $45.5 \%$, respectively. However, the studies on $\mathrm{CO}_{2}$ enrichment in medicinal plants are relatively limited compared to those on the other plants.

Light is an energy source for plant photosynthesis and an essential for plant growth, development, and bioactive compound accumulation. To achieve significant levels of plant cultivation in artificial facilities, it is important to set appropriate environmental conditions, especially with regard to light intensity. Plants grown under low light intensity have frequently been found to be more susceptible to photoinhibition than in high light intensity [16]. Previous studies have shown a decrease in the photosynthesis of eggplant [17] and reduced dry weight of wheat [18] under the weak light conditions. The long-term weak lighting conditions resulted in smaller leaf areas and thinner leaves [19]. On the other hand, too high light intensity also has negative effect on plant growth. This induces leaf wilting and reduces leaf area, chlorophyll content, and photosynthesis efficiency [20]. It can also destroy photosynthetic systems and cause serious oxidative damage to leaf tissue [21].

Therefore, the objective of this study is to investigate the growth, photosynthesis, and bioactive compound content of medicinal plants, and consequently, find a suitable combination of $\mathrm{CO}_{2}$ concentration and light intensity for high-quality mass production in a closed-type plant production system (CPPS).

\section{Results and Discussion}

\subsection{Growth Characteristics}

The different shoot growth characteristics of $G$. littoralis, as affected by various $\mathrm{CO}_{2}$ concentrations and light intensities after 56 days of treatment, are shown in Figure 1 and Table 1 . The petiole length was the longest at $8.8 \mathrm{~cm}$ in the $500 \mu \mathrm{mol} \cdot \mathrm{mol}^{-1} \mathrm{CO}_{2}$ concentration with $100 \mu \mathrm{mol} \cdot \mathrm{m}^{-2} \cdot \mathrm{s}^{-1} \mathrm{PPFD}$, while the leaf area was the widest at $142.78 \mathrm{~cm}^{2}$ in the $500 \mu \mathrm{mol} \cdot \mathrm{mol}^{-1}$ with 300 PPFD (Figure 1B and Table 1). The crown diameter, number of leaves, fresh weight (FW), and dry weight (DW) of the shoots were the lowest in the $500 \mu \mathrm{mol} \cdot \mathrm{mol}^{-1}$ with $100 \mu \mathrm{mol} \cdot \mathrm{m}^{-2} \cdot \mathrm{s}^{-1} \mathrm{PPFD}$. The growth of shoots was more affected by the light intensity than by the $\mathrm{CO}_{2}$ concentration, and the growth of $G$. littoralis in higher light intensity $\left(300 \mu \mathrm{mol} \cdot \mathrm{m}^{-2} \cdot \mathrm{s}^{-1} \mathrm{PPFD}\right)$ was higher compared lower light intensity $\left(100 \mu \mathrm{mol} \cdot \mathrm{m}^{-2} \cdot \mathrm{s}^{-1} \mathrm{PPFD}\right)$. An appropriate light intensity is a major factor for growth, morphogenesis, and other physiological 
responses [22,23]. Plants grown in a low light intensity have frequently been shown to display more photoinhibition than those grown under a high light intensity [24]. A low light intensity condition may lead to stretching of leaf length, leaf width, and plant height [25]. The G. littoralis showed an insignificant difference in the specific leaf area (SLA) (data are not shown) but the petiole length was stretched.
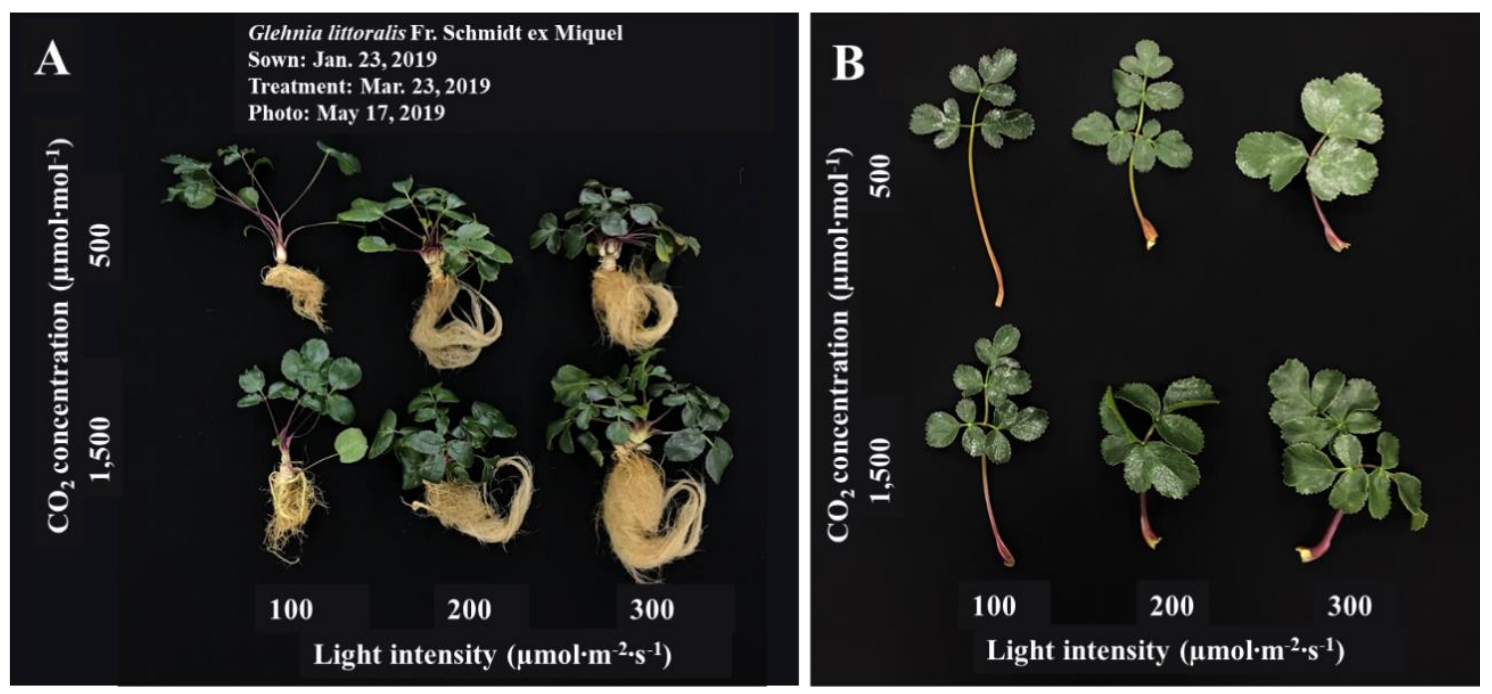

Figure 1. Images of the growth of the whole plant (A) and leaf (B) of Glehnia littoralis Fr. Schmidt ex Miquel as affected by different $\mathrm{CO}_{2}$ concentrations and light intensities.

Table 1. The different shoot growth characteristics of Glehnia littoralis Fr. Schmidt ex Miquel, as affected by various $\mathrm{CO}_{2}$ concentrations and light intensities after 56 days of treatment $(n=3)$.

\begin{tabular}{|c|c|c|c|c|c|c|c|}
\hline $\begin{array}{c}\mathrm{CO}_{2} \text { Concentration } \\
\left(\mu \mathrm{mol} \cdot \mathrm{mol}^{-1}\right)(\mathrm{A})\end{array}$ & $\begin{array}{c}\text { Light Intensity } \\
\left(\mu \mathrm{mol} \cdot \mathrm{m}^{-2} \cdot \mathrm{s}^{-1}\right)(\mathrm{B})\end{array}$ & $\begin{array}{c}\text { Petiole } \\
\text { Length }(\mathrm{cm})\end{array}$ & $\begin{array}{l}\text { Leaf Area } \\
\left(\mathrm{cm}^{2} / \text { plant }\right)\end{array}$ & $\begin{array}{c}\text { Crown } \\
\text { Diameter }(\mathrm{mm})\end{array}$ & $\begin{array}{l}\text { No. of } \\
\text { Leaves }\end{array}$ & $\begin{array}{l}\text { Fresh Weight } \\
\text { (g/plant) }\end{array}$ & $\begin{array}{c}\text { Dry Weight } \\
\text { (g/plant) }\end{array}$ \\
\hline \multirow{2}{*}{500} & 100 & $8.8 \pm 0.9 \mathrm{a}^{\mathrm{z}}$ & $82.65 \pm 13.1 \mathrm{bc}$ & $8.0 \pm 0.6 \mathrm{bc}$ & $8.0 \pm 0.6 \mathrm{bc}$ & $5.93 \pm 1.1 \mathrm{bc}$ & $1.28 \pm 0.2 \mathrm{bc}$ \\
\hline & 200 & $7.0 \pm 0.7 \mathrm{ab}$ & $112.23 \pm 19.7 \mathrm{ab}$ & $13.5 \pm 2.1 \mathrm{ab}$ & $12.2 \pm 2.1 \mathrm{ab}$ & $8.19 \pm 1.7 \mathrm{ab}$ & $1.61 \pm 0.4 \mathrm{ab}$ \\
\hline \multirow{3}{*}{1500} & 100 & $6.6 \pm 0.7 \mathrm{ab}$ & $46.60 \pm 9.5 \mathrm{c}$ & $7.6 \pm 0.5 c$ & $6.8 \pm 1.4 \mathrm{c}$ & $3.12 \pm 0.6 \mathrm{c}$ & $0.58 \pm 0.1 \mathrm{c}$ \\
\hline & 200 & $5.0 \pm 0.3 b$ & $104.33 \pm 15.1 \mathrm{ab}$ & $14.7 \pm 1.4 \mathrm{a}$ & $16.5 \pm 1.2 \mathrm{a}$ & $7.55 \pm 1.2 \mathrm{ab}$ & $1.53 \pm 0.2 \mathrm{ab}$ \\
\hline & 300 & $5.2 \pm 0.2 \mathrm{~b}$ & $107.04 \pm 17.7 \mathrm{ab}$ & $13.8 \pm 0.6 \mathrm{a}$ & $12.7 \pm 1.4 \mathrm{ab}$ & $9.15 \pm 1.1 \mathrm{ab}$ & $2.01 \pm 0.2 \mathrm{ab}$ \\
\hline Significance ${ }^{y}$ & $\mathrm{~A} \times \mathrm{B}$ & NS & NS & NS & NS & NS & NS \\
\hline
\end{tabular}

${ }^{\mathrm{z}}$ Mean separation within columns using Tukey's multiple range test at $p \leq 0.05 .{ }^{\mathrm{y}} \mathrm{NS},{ }^{*},{ }^{* *},{ }^{* * *}$ Nonsignificant or significant at $p \leq 0.05,0.01$, or 0.001 , respectively.

The root growth characteristics, such as the root length, root diameter, FW, and DW of the roots are shown in Table 2. The root growth was closely associated with the light condition for the shoot growth [26]. The root length was the shortest in the $100 \mu \mathrm{mol} \cdot \mathrm{m}^{-2} \cdot \mathrm{s}^{-1} \mathrm{PPFD}$, regardless of the $\mathrm{CO}_{2}$ concentration, at 10.7 and $11.3 \mathrm{~cm}$ for the 500 and $1500 \mu \mathrm{mol} \cdot \mathrm{mol}^{-1}$ concentration, respectively. The root diameter was the thinnest at $6.50 \mathrm{~mm}$ in the $1500 \mu \mathrm{mol} \cdot \mathrm{mol}^{-1}$ with $100 \mu \mathrm{mol} \cdot \mathrm{m}^{-2} \cdot \mathrm{s}^{-1}$ PPFD. Furthermore, the FW and DW of roots displayed a positive correlation in which the weight increased as the light intensity increased. The root growth was not affected by the $\mathrm{CO}_{2}$ concentration but, a change in the light intensity produced a significant difference. Nager et al. [27] reported that a high light intensity $\left(300 \mu \mathrm{mol} \cdot \mathrm{m}^{-2} \cdot \mathrm{s}^{-1} \mathrm{PPFD}\right)$ enhanced the FW of the roots of Nicotiana tabacum. Similarly, Olschowski et al. [28] obtained a heavier root DW of Calibrachoa in a high light intensity when cutting. Kitaya et al. [29] suggested that an optimal PPFD can rapidly produce high-quality lettuce plug seedlings. 
Table 2. The different root growth characteristics of Glehnia littoralis Fr. Schmidt ex Miquel, as affected by various $\mathrm{CO}_{2}$ concentrations and light intensities after 56 days of treatment $(n=3)$.

\begin{tabular}{|c|c|c|c|c|c|}
\hline $\begin{array}{l}\mathrm{CO}_{2} \text { Concentration } \\
\left(\mu \mathrm{mol} \cdot \mathrm{mol}^{-1}\right)(\mathrm{A})\end{array}$ & $\begin{array}{c}\text { Light Intensity } \\
\left(\mu \mathrm{mol} \cdot \mathrm{m}^{-2} \cdot \mathrm{s}^{-1}\right)(\mathrm{B})\end{array}$ & Root Length (cm) & Root Diameter (mm) & Fresh Weight (g/plant) & Dry Weight (g/plant) \\
\hline \multirow{3}{*}{500} & 100 & $10.7 \pm 0.4 b^{z}$ & $9.6 \pm 0.5 \mathrm{ab}$ & $4.53 \pm 0.2 \mathrm{~cd}$ & $1.20 \pm 0.1 \mathrm{c}$ \\
\hline & 200 & $29.9 \pm 1.5 \mathrm{a}$ & $11.0 \pm 0.3 \mathrm{a}$ & $11.60 \pm 2.4 \mathrm{ab}$ & $1.68 \pm 0.4 b c$ \\
\hline & 300 & $26.3 \pm 2.2 \mathrm{a}$ & $12.0 \pm 0.7 \mathrm{a}$ & $16.60 \pm 0.7 \mathrm{a}$ & $2.71 \pm 0.1 \mathrm{a}$ \\
\hline \multirow{3}{*}{1500} & 100 & $11.3 \pm 0.5 b$ & $6.5 \pm 0.8 b$ & $3.81 \pm 0.7 \mathrm{~d}$ & $0.80 \pm 0.2 \mathrm{c}$ \\
\hline & 200 & $25.5 \pm 1.6 \mathrm{a}$ & $10.4 \pm 1.3 \mathrm{a}$ & $10.12 \pm 1.3 b c$ & $1.51 \pm 0.4 b c$ \\
\hline & 300 & $31.7 \pm 1.5 \mathrm{a}$ & $12.3 \pm 0.4 \mathrm{a}$ & $14.83 \pm 1.8 \mathrm{ab}$ & $2.20 \pm 0.2 \mathrm{ab}$ \\
\hline \multirow{3}{*}{ Significance ${ }^{\mathrm{y}}$} & A & NS & NS & NS & NS \\
\hline & B & $* * *$ & $* * *$ & $* * *$ & $* * *$ \\
\hline & $\mathrm{A} \times \mathrm{B}$ & $* *$ & NS & NS & NS \\
\hline
\end{tabular}

${ }^{\mathrm{z}}$ Mean separation within columns using Tukey's multiple range test at $p \leq 0.05 .{ }^{\mathrm{y}} \mathrm{NS},{ }^{* *},{ }^{* * *}$ Nonsignificant or significant at $p \leq 0.01$ or 0.001 , respectively.

\subsection{Photosynthetic Rate and the SPAD Value}

The $\mathrm{CO}_{2}$ concentration and light intensity significantly affected the photosynthetic rate in G. littoralis (Figure 2A). The photosynthetic rate was the highest in the $1500 \mu \mathrm{mol} \cdot \mathrm{mol}^{-1} \mathrm{CO}_{2}$ concentration with the $300 \mu \mathrm{mol} \cdot \mathrm{m}^{-2} \cdot \mathrm{s}^{-1}$ PPFD in $6.8 \mu \mathrm{mol} \mathrm{CO} \mathrm{Cm}^{-2} \cdot \mathrm{s}^{-1}$, while the lowest was found in the $500 \mu \mathrm{mol} \cdot \mathrm{mol}^{-1} \mathrm{CO}_{2}$ concentration with $100 \mu \mathrm{mol} \cdot \mathrm{m}^{-2} \cdot \mathrm{s}^{-1} \mathrm{PPFD}$ in $0.5 \mu \mathrm{mol} \mathrm{CO} \mathrm{m}^{-2} \cdot \mathrm{s}^{-1}$. The photosynthetic rate showed a positive correlation with $\mathrm{CO}_{2}$ concentration and the light intensity. The SPAD did not show a significant difference (Figure 2B). Zheng et al. [30] reported that a high light intensity $\left(350 \mu \mathrm{mol} \cdot \mathrm{m}^{-2} \cdot \mathrm{s}^{-1}\right.$ PPFD) increased the photosynthetic capacity of the mother plant and the primary runner plant of strawberry. Furthermore, $\mathrm{CO}_{2}$ enrichment increased the photosynthetic rate of Gerbera jamesonii [31]. G. littoralis is a crop native to coastal dunes and grows in high-light natural environments. Similar results showed that the growth of Peucedanum japonicum Thunberg, which is native to the seashore, was also efficient at increasing growth and production in a high light intensity $\left(200 \mu \mathrm{mol} \cdot \mathrm{m}^{-2} \cdot \mathrm{s}^{-1} \mathrm{PPFD}\right)$ than in a low light intensity $\left(60 \mu \mathrm{mol} \cdot \mathrm{m}^{-2} \cdot \mathrm{s}^{-1} \mathrm{PPFD}\right)[32]$.

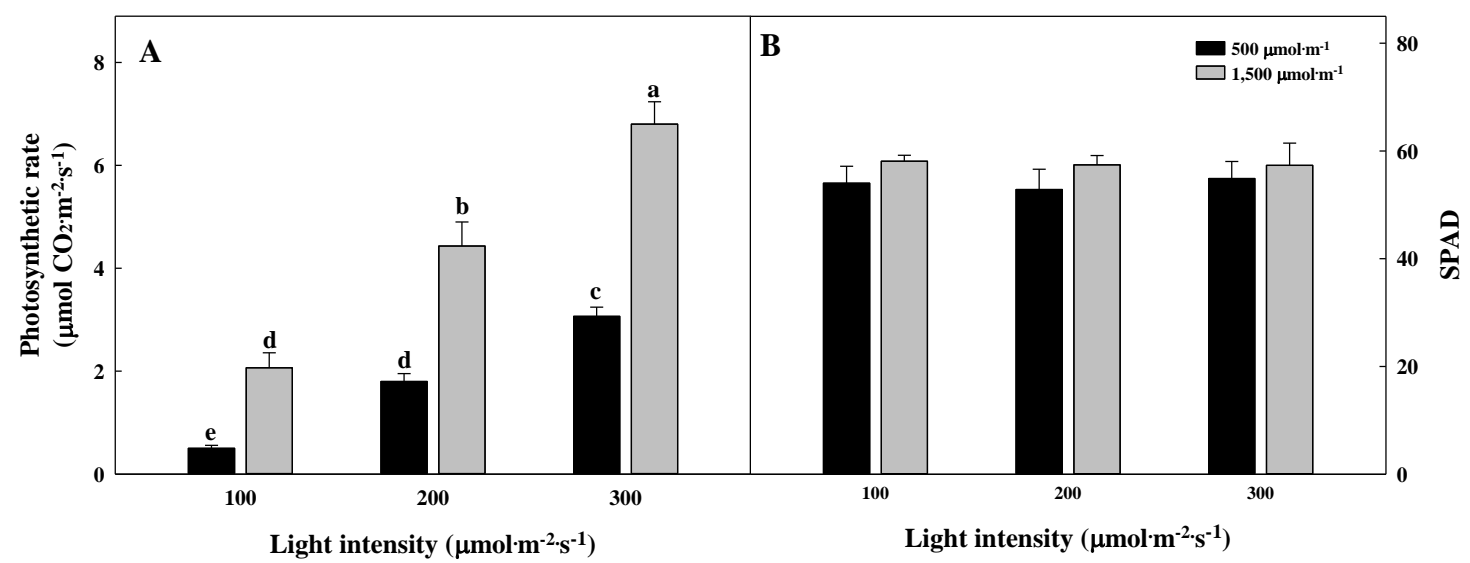

Figure 2. Photosynthetic rate (A) and SPAD (B) of Glehnia littoralis Fr. Schmidt ex Miquel, as affected by various $\mathrm{CO}_{2}$ concentrations and light intensities 56 days of treatment. The vertical bars represent the standard deviation of the mean $(n=3)$. Different letters above bars indicate significant differences at $p \leq 0.05$, using Tukey's multiple range test.

\subsection{Total Sugar and Starch}

The high light intensity increased the total sugar and starch contents in G. littoralis. However, the $\mathrm{CO}_{2}$ concentration did not influence the total sugar and starch contents. The total sugar and starch contents were the highest in the $300 \mu \mathrm{mol} \cdot \mathrm{m}^{-2} \cdot \mathrm{s}^{-1} \mathrm{PPFD}$ regardless of the $\mathrm{CO}_{2}$ concentration (Figure 3). In a $\mathrm{CO}_{2}$ concentration of $500 \mu \mathrm{mol} \cdot \mathrm{mol}^{-1}$, the total sugar and starch contents were higher in the $300 \mu \mathrm{mol} \cdot \mathrm{m}^{-2} \cdot \mathrm{s}^{-1}$ PPFD by 5.4 and 2.2 times compared to the $100 \mu \mathrm{mol} \cdot \mathrm{m}^{-2} \cdot \mathrm{s}^{-1}$ PPFD, respectively. Many studies have reported that $\mathrm{CO}_{2}$ enrichment increases the sugar and starch 
contents [33-35], which is inconsistent with this study. G. littoralis, a halophyte with developed water storage tissue that stores a lot of water in the cell, is considered to be less sensitive to $\mathrm{CO}_{2}$ concentrations because of its thick leaves. The leaf is a photosynthetic organ, and the area and thickness are the major factors affecting the growth of the plant. To absorb sufficient light energy, the leaves are as wide as possible, and at the same time to facilitate gas exchange $\left(\mathrm{CO}_{2}, \mathrm{O}_{2}\right.$, and $\left.\mathrm{H}_{2} \mathrm{O}\right)$, the leaves are as flat and thin as possible [36]. The higher light intensity can positively affect the accumulation of assimilates, such as proteins, and the starch, and sugar of spinach increased in the $300 \mu \mathrm{mol} \cdot \mathrm{m}^{-2} \cdot \mathrm{s}^{-1} \mathrm{PPFD}$ than those in the $100 \mu \mathrm{mol} \cdot \mathrm{m}^{-2} \cdot \mathrm{s}^{-1}$ PPFD [37]. In Glycine max (Linn.) Merr., a high light intensity induced photosynthetic activity, increasing the soluble sugar, sucrose, and starch contents in the shoots and roots [38].

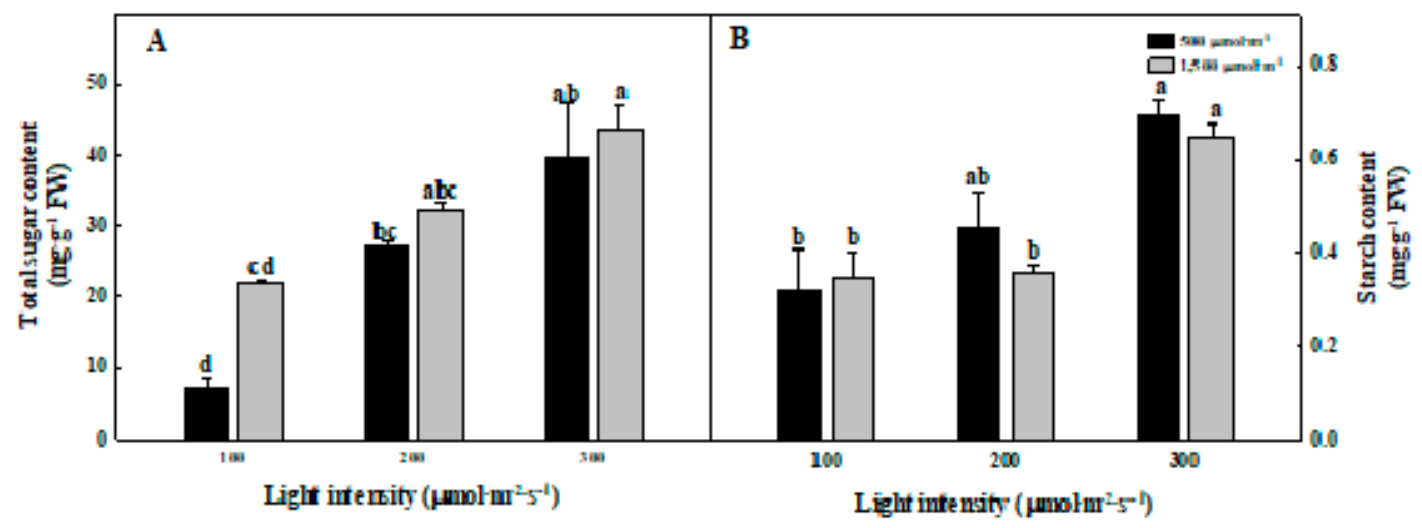

Figure 3. The different total sugar (A) and starch (B) contents of Glehnia littoralis Fr. Schmidt ex Miquel, as affected by various $\mathrm{CO}_{2}$ concentrations and light intensities after 56 days of treatment. The vertical bars represent the standard deviation of the mean $(n=3)$. Different letters above bars indicate significant differences at $p \leq 0.05$, using Tukey's multiple range test.

\subsection{Harvest Yield}

G. littoralis can be harvested cyclically by taking a leaf. The $\mathrm{CO}_{2}$ enrichment did not have a significant effect on the harvest yield or the change in the number of leaves from the harvest to the re-harvest. However, the low light intensity condition affected the harvest yield. The first and second harvest yields, at 61 days and 96 days of treatment, are shown in Figure 4A,B, respectively. It was observed that the yield of G. littoralis was high in the light intensity of more than the $200 \mu \mathrm{mol} \cdot \mathrm{m}^{-2} \cdot \mathrm{s}^{-1}$ PPFD, where the harvest yield increased by more than twice as much during the second harvest compared to the first harvest in the $1500 \mu \mathrm{mol} \cdot \mathrm{mol}^{-1} \mathrm{CO}_{2}$ concentration with $300 \mu \mathrm{mol} \cdot \mathrm{m}^{-2} \cdot \mathrm{s}^{-1} \mathrm{PPFD}$. However, regardless of the $\mathrm{CO}_{2}$ concentration, there was no significant difference between the first and second harvest yields in the $100 \mu \mathrm{mol} \cdot \mathrm{m}^{-2} \cdot \mathrm{s}^{-1} \mathrm{PPFD}$. This was because the high light intensity significantly affected the root development of $G$. littoralis and sufficient roots were produced for new leaf production. The change in the number of leaves from the harvest to the re-harvest is shown in Figure 5 . The number of leaves was only affected by the light intensity, and in particular, leaves were developed the most in the $300 \mu \mathrm{mol} \cdot \mathrm{m}^{-2} \cdot \mathrm{s}^{-1}$ PPFD. Lee et al. [39] reported that new leaf emergence and biomass accumulation were promoted at a higher apparent daily light integral level. Furthermore, the higher light intensity produced more primary and total plant runners of strawberry. 


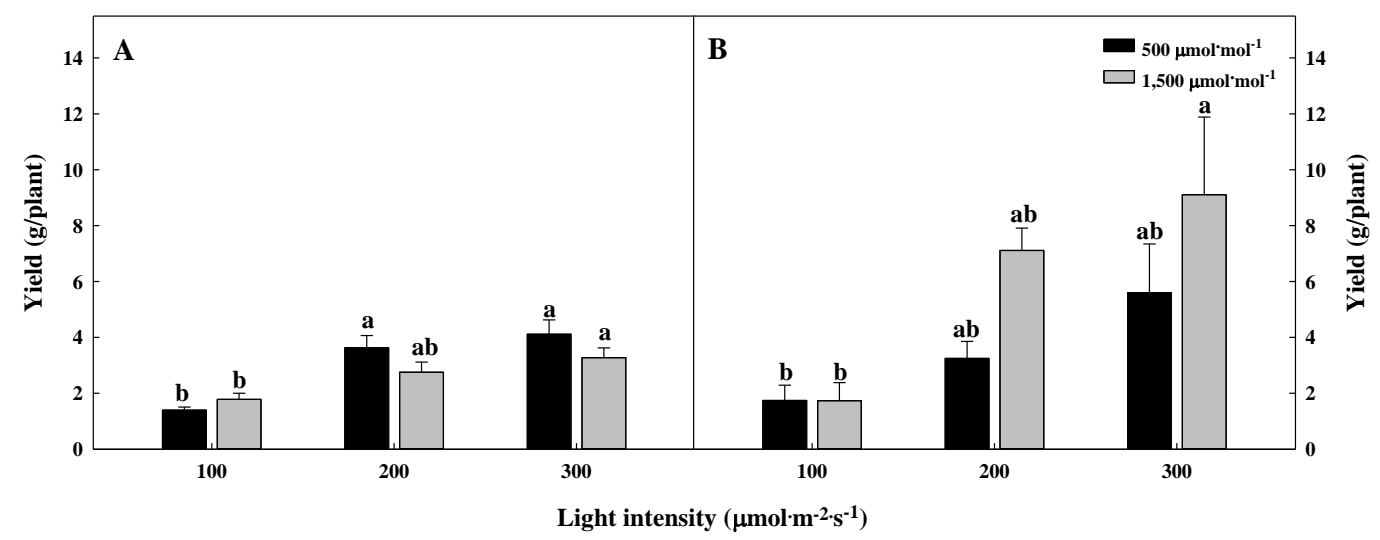

Figure 4. The different first (A) and second (B) harvest yields of Glehnia littoralis Fr. Schmidt ex Miquel, as affected by various $\mathrm{CO}_{2}$ concentrations and light intensities after 56 days of treatment. The vertical bars represent the standard deviation of the mean $(n=3)$. Different letters above bars indicate significant differences at $p \leq 0.05$, using Tukey's multiple range test.

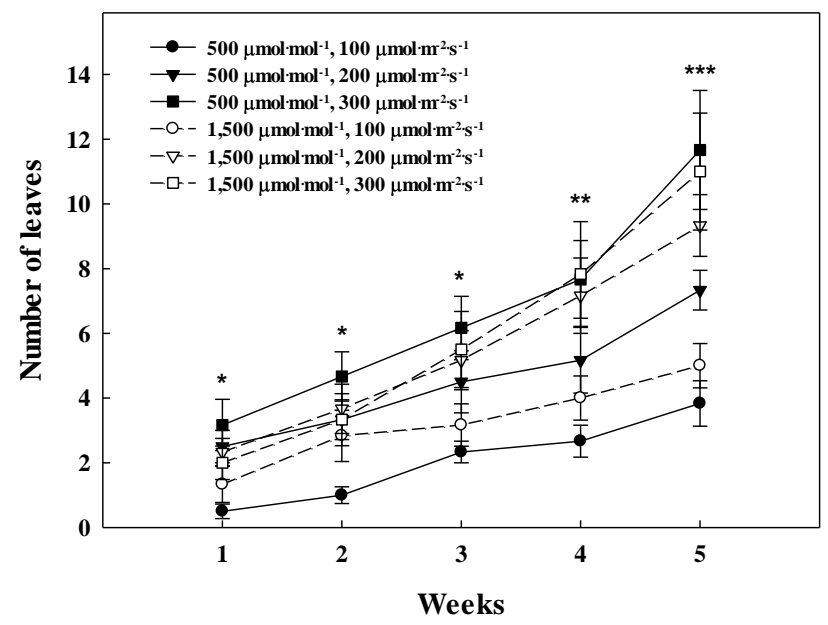

Figure 5. Changes in the number of leaves on Glehnia littoralis Fr. Schmidt ex Miquel, as affected by various $\mathrm{CO}_{2}$ concentrations and light intensities. The error bars represent the standard deviation of the mean $(n=3) . * * * * * *$ Significant at $p \leq 0.05,0.01$, or 0.001 , respectively.

\subsection{Bioactive Compound}

The chlorogenic acid and total saponin concentrations per DW or FW of G. littoralis were not significantly different between the treatments (Figures 6A and 7A). On the other hand, the chlorogenic acid and total saponin contents per biomass were the greatest in the $300 \mu \mathrm{mol} \cdot \mathrm{m}^{-2} \cdot \mathrm{s}^{-1}$ PPFD regardless of the $\mathrm{CO}_{2}$ concentration (Figures $6 \mathrm{~B}$ and $7 \mathrm{~B}$ ). In a $\mathrm{CO}_{2}$ concentration of $500 \mu \mathrm{mol} \cdot \mathrm{mol}^{-1}$, the chlorogenic acid and total saponin contents per biomass were higher in the $300 \mu \mathrm{mol} \cdot \mathrm{m}^{-2} \cdot \mathrm{s}^{-1}$ PPFD by 1.6 and 6.3 times compared to in the $100 \mu \mathrm{mol} \cdot \mathrm{m}^{-2} \cdot \mathrm{s}^{-1} \mathrm{PPFD}$, respectively. In other studies, $\mathrm{CO}_{2}$ enrichment improved the nutritional qualities but the total free phenolic acids and chicoric acid contents of lettuce significantly decreased; the reaction to the elevated $\mathrm{CO}_{2}$ concentration was found to be dependent on the plant species $[40,41]$. The accumulation of bioactive compounds is induced by the increased soluble sugar acting as a precursor that promotes the synthesis and accumulation of antioxidants [42-44]. The polyphenol content of lettuce grown in a $350 \mu \mathrm{mol} \cdot \mathrm{m}^{-2} \cdot \mathrm{s}^{-1} \mathrm{PPFD}$ was significantly higher than that of plants grown in a $180 \mu \mathrm{mol} \cdot \mathrm{m}^{-2} \cdot \mathrm{s}^{-1}$ PPFD [45]. In this study, there was no difference in the concentration of total chlorogenic acid per DW or total saponin per FW, but the production of bioactive compounds increased in the $300 \mu \mathrm{mol} \cdot \mathrm{m}^{-2} \cdot \mathrm{s}^{-1} \mathrm{PPFD}$, which displayed high photosynthesis and superior growth. 


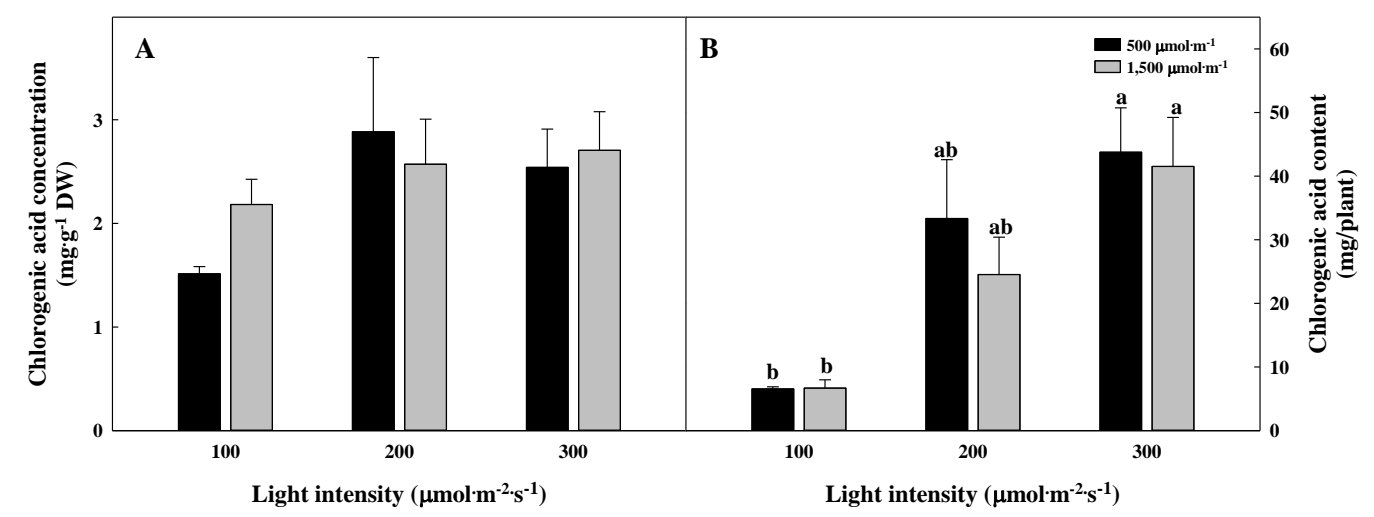

Figure 6. The different chlorogenic acid concentrations (A) and contents per biomass (B) of Glehnia littoralis Fr. Schmidt ex Miquel shoots, as affected by various $\mathrm{CO}_{2}$ concentrations and light intensities after 56 days of treatment. The vertical bars represent the standard deviation of the mean $(n=3)$. Different letters above bars indicate significant differences at $p \leq 0.05$, using Tukey's multiple range test.

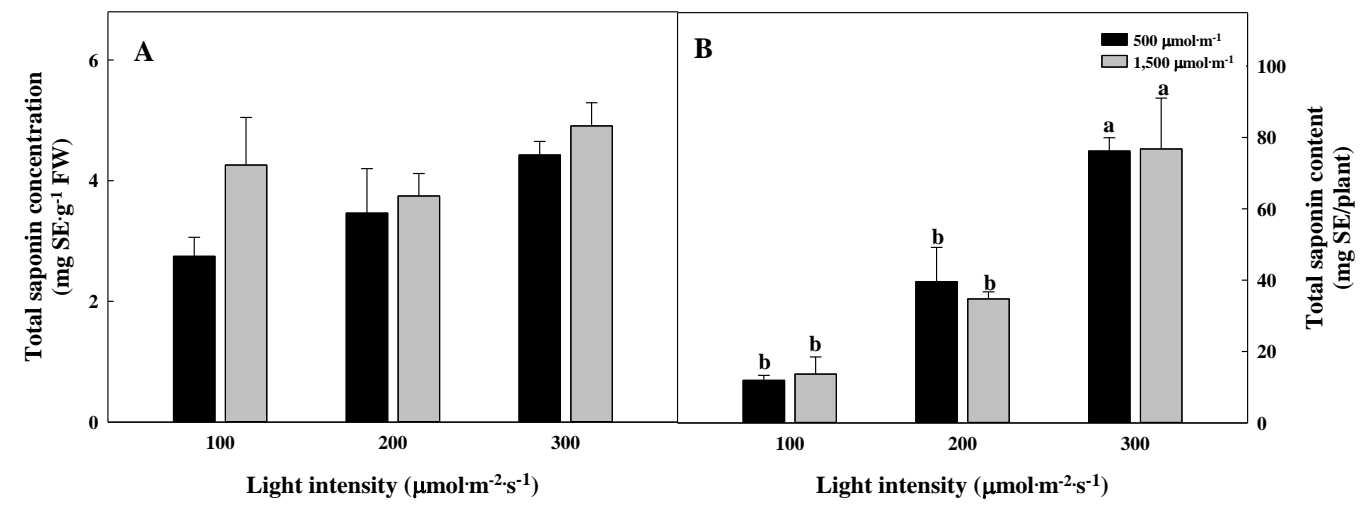

Figure 7. The different total saponin concentration (A) and content per biomass (B) of Glehnia littoralis Fr. Schmidt ex Miquel shoots, as affected by various $\mathrm{CO}_{2}$ concentrations and light intensities after 56 days of treatment. The vertical bars represent the standard deviation of the mean $(n=3)$. Different letters above bars indicate significant differences at $p \leq 0.05$, using Tukey's multiple range test.

\section{Materials and Methods}

\subsection{Plant Materials and Growth Condition}

The G. littoralis seeds were sown in a Petri dish and the seedlings were placed in 128-hole plug trays filled with urethane sponge (Hydroponic Sponge, Easyhydro Co. Ltd., Chuncheon, Korea) in a CPPS (C1200H3, FC Poibe Co. Ltd., Seoul, Korea) at a temperature of $20 \pm 1{ }^{\circ} \mathrm{C}$, relative humidity (RH) of $60 \pm 10 \%$, a photoperiod of $12 / 12 \mathrm{~h}$ (light/dark), and a $150 \mu \mathrm{mol} \cdot \mathrm{m}^{-2} \cdot \mathrm{s}^{-1}$ PPFD using RGB (red:green:blue $=$ 7:1:2) LEDs (ES LEDs Co. Ltd., Seoul, Korea). The 60-day-old seedlings were transplanted into a deep floating technique system with recycling Hoagland nutrient solution [46] in a CPPS. The plants were cultured for 96 days at a temperature of $20 \pm 1{ }^{\circ} \mathrm{C}, \mathrm{RH}$ of $60 \pm 10 \%$, and a photoperiod of $12 / 12 \mathrm{~h}$ (light/dark). The experimental treatments were set to $500 \mathrm{or} 1500 \mu \mathrm{mol} \cdot \mathrm{mol}^{-1}$ $\mathrm{CO}_{2}$ concentrations in combination with one of three light intensities: 100, 200, or $300 \mu \mathrm{mol} \cdot \mathrm{m}^{-2} \cdot \mathrm{s}^{-1}$ PPFD, which were provided by RGB (red:green:blue = 7:1:2) LEDs (Figure 8). In CPPS where $\mathrm{CO}_{2}$ concentration, photoperiod, and temperature are automatically controlled, the $\mathrm{CO}_{2}$ concentration was controlled by connecting a liquefied carbon dioxide tank and $\mathrm{CO}_{2}$ regulator. The $\mathrm{CO}_{2}$ concentration, temperature, and RH were monitored during the cultivation period using a data logger (TR-76Ui, T\&D Co. Ltd., Nagano, Japan). The light intensity was set using a photometer (HD2101.2, Delta Ohm SrL, Caselle, Italy). 


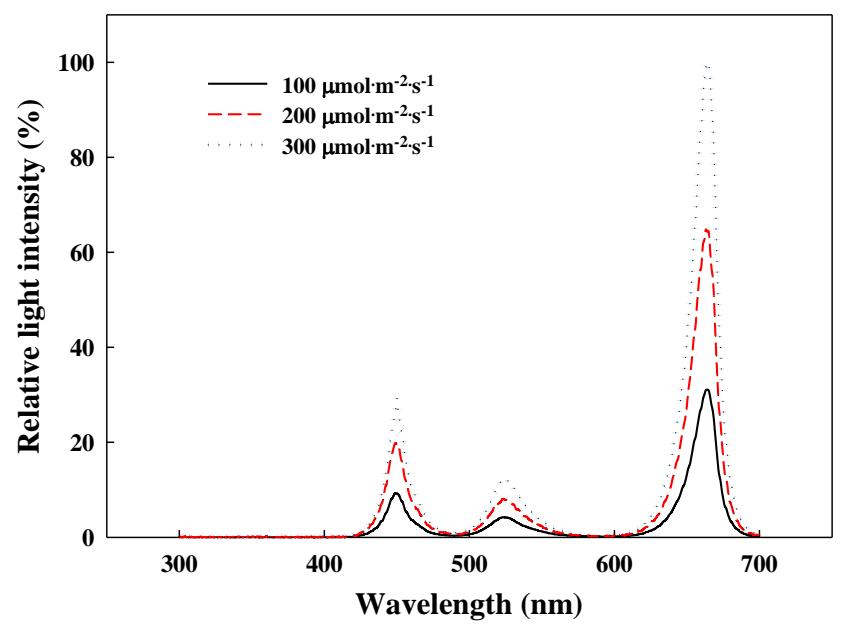

Figure 8. Relative spectral distribution of the RGB LEDs (red:green:blue $=7: 1: 2$ ) used in a closed-type plant production system.

\subsection{Growth Characteristics}

After 56 days of treatment, the petiole length, crown and root diameters, root length, FW and DW of the shoots and roots, number of leaves, and leaf area were measured. The FW was investigated using an electronic balance (EW220-3NM, Kern \& Sohn GmbH., Balingen, Germany) and the DW was investigated after drying in an oven (Venticell-220, MMM Medcenter Einrichtunger GmbH., Planegg, Germany) at $70{ }^{\circ} \mathrm{C}$ for $72 \mathrm{~h}$. The crown and root diameter were measured using Vernier calipers (CD-20CPX, Mitutoyo Co. Ltd., Kawasaki, Japan). The leaf area was measured using a leaf area meter (LI-3000, LI-COR Inc., Lincoln, NE, USA). Photosynthetic rate was measured using a portable photosynthesis system (CIRAS-3, PP Systems International Inc., Amesbury, MA, USA) on the fully unfolded fifth leaf from the top. The measurement conditions were controlled as follows: leaf area $4.5 \mathrm{~mm}^{2}$; leaf temperature $20{ }^{\circ} \mathrm{C}$; air flow rate $150 \mathrm{~mL} \cdot \mathrm{min}^{-1}$; 500 or $1500 \mu \mathrm{mol} \cdot \mathrm{mol}^{-1} \mathrm{CO}_{2}$ concentration; 100, 200, or $300 \mu \mathrm{mol} \cdot \mathrm{m}^{-2} \cdot \mathrm{s}^{-1} \mathrm{PPFD}$. The chlorophyll content was expressed as the SPAD, and measured using a portable chlorophyll meter (SPAD-502, Konica Minolta Inc., Tokyo, Japan). The first and second harvests were performed after treatment for 61 and 96 days, respectively, and the harvest yield was measured by weight of marketable leaves (over $15 \mathrm{~cm}^{2}$ of leaf area).

\subsection{Total Sugar and Starch}

For the total sugar content determination, the leaves of G. littoralis were ground with liquid nitrogen and stored in a deep freezer (NF-140SF, Nihon Freezer Co. Ltd., Yushima, Japan) at $-70{ }^{\circ} \mathrm{C}$. A $0.3 \mathrm{~g}$ sample was taken for each treatment. The samples were mixed with $10 \mathrm{~mL}$ of $80 \%$ ethanol and then ground for $1 \mathrm{~min}$. After being heated in a $60^{\circ} \mathrm{C}$ water bath, the supernatant was separated via centrifugation $\left(908 \times g, 20^{\circ} \mathrm{C}, 30 \mathrm{~min}\right)$. Then, $10 \mathrm{~mL}$ of $80 \%$ ethanol was added to the remaining precipitate, heated in a waterbath at $60{ }^{\circ} \mathrm{C}$ for $30 \mathrm{~min}$, and centrifuged under the same conditions. After the two centrifugations, the supernatant was diluted with a total of $40 \mathrm{~mL}$ of $80 \%$ ethanol. Then, $0.5 \mathrm{~mL}$ of $5 \%$ phenol reagent was added to the sample solution, vortexed, and $2.5 \mathrm{~mL}$ of $98 \%$ sulfuric acid were added and vortexed. After cooling at room temperature, the absorbance was measured at $490 \mathrm{~nm}$ using a spectrophotometer and the total sugar content was calculated using glucose as the standard.

For the starch determination, the leaves were ground with liquid nitrogen and stored in a deep freezer at $-70{ }^{\circ} \mathrm{C}$. Total of $0.3 \mathrm{~g}$ of sample was used for each treatment. To solubilize the sample, $10 \mathrm{~mL}$ of $80 \%$ ethanol was added, shaken for $30 \mathrm{~min}$, and then centrifuged at $300 \times g$ for $30 \mathrm{~min}$ at $20{ }^{\circ} \mathrm{C}$. Then, $40 \%$ ethanol was added to the residue, and centrifuged again under the same conditions. Then, $2 \mathrm{~mL}$ of $30 \% \mathrm{HClO}_{4}$ and $1 \mathrm{~mL}$ of dimethyl sulfoxide were added to the residue and kept at 
room temperature for $30 \mathrm{~min}$. Then, $2 \mathrm{~mL}$ of distilled water and $5 \mathrm{~mL}$ of $\mathrm{H}_{2} \mathrm{SO}_{4}$ were added, and the waterbath was used to maintain the temperature at $100{ }^{\circ} \mathrm{C}$ for $1 \mathrm{~h}$, then centrigugation was performed under $300 \times \mathrm{g}$ for $30 \mathrm{~min}$ at $20^{\circ} \mathrm{C}$. Around $0.5 \mathrm{~mL}$ of this sample solution was mixed with $0.5 \mathrm{~mL}$ of $5 \%$ phenol reagent, then vortexed, followed by the addition of $2.5 \mathrm{~mL}$ of $98 \%$ sulfuric acid and the vortexed. After cooling at room temperature, the absorbance was measured at $470 \mathrm{~nm}$ using a spectrophotometer, and the starch content was calculated using glucose as the standard.

\subsection{Bioactive Compounds}

\subsubsection{Chlorogenic Acid Concentration}

For the quantitative analysis of chlorogenic acid, $500 \mathrm{mg}$ of each powdered plant material were first mixed with $20 \mathrm{~mL}$ of $80 \%$ methanol and then shaken at $100 \mathrm{rpm}$ on an orbital shaker for $24 \mathrm{~h}$ at room temperature. Afterward, all of the supernatant was centrifuged at $4250 \times g$ for $5 \mathrm{~min}$. The supernatant was filtered through a $0.2 \mu \mathrm{m}$ syringe filter (25HP020AN, Advantech Co. Ltd., Asan, Korea) before being injected into a high-performance liquid chromatography device (Nexera, Shimadzu Corp., Kyoto, Japan) system equipped with an $4.6 \times 150 \mathrm{~mm}, 5 \mu \mathrm{m}$ column (Agilent Eclipse plus-C18, Agilent Technology Co Ltd., Santa Clara, CA, USA) and a guard column maintained at $30^{\circ} \mathrm{C}$. Solvents A (methanol) and B (trifluoroacetic acid) were used as the mobile phases. The gradient was as follows: $0 \mathrm{~min}, 100 \% \mathrm{~A}$; $3 \mathrm{~min}, 10 \% \mathrm{~B} ; 8 \mathrm{~min}, 30 \% \mathrm{~B} ; 30 \mathrm{~min}, 50 \% \mathrm{~B} ; 40 \mathrm{~min}, 60 \% \mathrm{~B} ; 50 \mathrm{~min}, 100 \% \mathrm{~B}$; held constant for $10 \mathrm{~min}$. The flow rate was $0.8 \mathrm{~mL} \cdot \mathrm{min}-1$ and the injection volume was $10 \mu \mathrm{L}$. The chromatogram was monitored at $270 \mathrm{~nm}$ using photodiode array detection. To present the chlorogenic acid, concentrations of the derivatized samples, standard curves were prepared using 3-(3,4-dihydroxycinnamoyl) quinic acid (chlorogenic acid, Sigma-Aldrich Co. Ltd., St. Louis, MO, USA). Then, the calculated values were converted to the concentrations in terms of milligrams of chlorogenic acid, per grams of DW of the samples.

\subsubsection{Total Saponin Concentration}

To measure the total saponin concentration of the root, the total saponin content was extracted using a method modified from [47]. About $0.5 \mathrm{~g}$ root powder was defatted with $10 \mathrm{~mL}$ of petroleum ether by shaking it for $4 \mathrm{~h}$, and then the residues were extracted twice, each with $5 \mathrm{~mL}$ of $80 \%$ aqueous methanol, by shaking for $4 \mathrm{~h}$ each time on an orbit shaker. The extracts were stored at $4{ }^{\circ} \mathrm{C}$ in the dark for later use. Approximately $100 \mu \mathrm{L}$ of the extract was mixed with $400 \mu \mathrm{L}$ of $80 \%$ methanol, $500 \mu \mathrm{L}$ of $8 \%$ vanillin solution, and $5 \mathrm{~mL}$ of $72 \%$ sulfuric acid. After the mixture was heated in a water bath at $60^{\circ} \mathrm{C}$ for $10 \mathrm{~min}$, it was cooled in ice-cold water. The absorbance of the supernatant was measured using a spectrophotometer at $544 \mathrm{~nm}$ to determine the total saponin concentration, which was expressed as milligrams of saponin equivalent (SE) per grams of fresh weight.

\subsection{Statistical Analysis}

The experiment involved three replicates and ten plants per replicate, and was laid out in a completely randomized block design. After selecting uniform plants, three plants per replicate were used to determine the plant growth parameters and three plants per replicate were used to determine the photosynthetic rate; the total sugar, starch, and bioactive compounds; and the harvest yield. The statistical analyses were carried out using the SAS program (SAS 9.4, SAS Institute Inc., Cary, NC, USA). The experimental results were subjected to an analysis of variance (ANOVA) and Tukey's multiple range tests. Graphing was performed with the SigmaPlot program (SigmaPlot 12.0, Systat Software Inc., Palo Alto, CA, USA).

\section{Conclusions}

This study focused on the effects of $\mathrm{CO}_{2}$ concentration (500 or $1500 \mu \mathrm{mol} \cdot \mathrm{mol}^{-1}$ ) and light intensity $\left(100,200\right.$, or $\left.300 \mu \mathrm{mol} \cdot \mathrm{m}^{-2} \cdot \mathrm{s}^{-1} \mathrm{PPFD}\right)$ on the growth, photosynthetic rate, and bioactive 
compound content of G. littoralis to find an appropriate $\mathrm{CO}_{2}$ concentration and light intensity for the high-quality, mass production of medicinal plants grown in a CPPS. The G. littoralis was not affected by the $\mathrm{CO}_{2}$ concentration, while a high light intensity increased the growth, bioactive compound content, and harvest yield. The data showed that a $300 \mu \mathrm{mol} \cdot \mathrm{m}^{-2} \cdot \mathrm{s}^{-1} \mathrm{PPFD}$ greatly enhanced the plant production in a CPPS.

Author Contributions: Conceptualization, S.J.H.; methodology, H.R.L. and S.J.H.; software, H.R.L.; validation, H.R.L., H.M.K., and H.R.L.; formal analysis, H.R.L.; investigation, H.R.L., H.M.K., and H.W.J.; resources, S.J.H.; data curation, H.R.L.; writing—original draft preparation, H.R.L.; writing—review and editing, S.J.H.; visualization, H.R.L.; supervision, S.J.H.; project administration, H.R.L., M.M.O.; funding acquisition, M.M.O., S.J.H. All authors have read and agreed to the published version of the manuscript.

Funding: This research was funded by the "Cooperative Research Program for Agriculture Science \& Technology Development (Project No. PJ01385201)" Rural Development Administration, Korea.

Acknowledgments: This work was carried out with the support of the "Cooperative Research Program for Agriculture Science \& Technology Development (Project No. PJ01385201)" Rural Development Administration, Korea.

Conflicts of Interest: The authors declare no conflict of interest.

\section{References}

1. Ministry of Food and Drug Safety (MFDS). Food \& Drug Statistical Yearbook; Ministry of Food and Drug Safety: Cheongju, Korea, 2018.

2. Ministry of Agriculture, Food and Rural Affairs (MAFRA). Production Performance of Industrial Crop; Ministry of Agriculture, Food and Rural Affairs: Sejong, Korea, 2018.

3. Seo, Y.K.; Ryu, K.S. Study on the component of Glehniae Radix. Korean J. Pharmacogn. 1977, 7, 233-235.

4. Yuan, Z.; Tezuka, Y.; Fan, W.; Kadota, S.; Li, X. Constituents of the underground parts of Glehnia littoralis. Chem. Pharm. Bull. 2002, 50, 73-77. [CrossRef] [PubMed]

5. Kim, S.J.; Chin, Y.W.; Yoon, K.D.; Ryu, M.Y.; Lee, J.H.; Kim, J.W. Chemical constituents of Saposhnikovia divaricate. Korean J. Pharmacogn. 2008, 39, 357-364.

6. Jia, Z.; Tang, M.; Wu, J. The determination of flavonoid contents in mulberry and their scavenging effects on superoxide radicals. Food Chem. 1999, 64, 555-559.

7. Blois, M.S. Antioxidant determinations by the use of a stable free radical. Nature 1958, 181, 1199-1200. [CrossRef]

8. McMurtrie, R.E.; Wang, Y.P. Mathematical models of the photosynthetic response of tree stands to rising $\mathrm{CO}_{2}$ concentration and temperatures. Plant Cell Environ. 1993, 16, 1-13. [CrossRef]

9. Leadley, P.W.; Niklaus, P.A.; Stocker, R. A field study of the effects of elevated $\mathrm{CO}_{2}$ on plant biomass and community structure in a calcareous grassland. Oecologia 1999, 118, 39-49. [CrossRef]

10. Ainsworth, E.A.; Rogers, A. The response of photosynthesis and stomatal conductance to rising $\left[\mathrm{CO}_{2}\right]$ : Mechanisms and environmental interactions. Plant Cell Environ. 2007, 30, 258-270. [CrossRef]

11. Xu, Z.Z.; Xhimizu, H.; Yagasaki, Y.; Ito, S.; Zheng, Y.R.; Zhou, G.S. Interactive effects of elevated $\mathrm{CO}_{2}$ drought, and warming on plants. J. Plant Growth Regul. 2013, 32, 692-707. [CrossRef]

12. Prior, S.A.; Brett Runion, G.; Rogers, H.H.; Torbert, H.A.; Reeves, D.W. Elevated atmospheric $\mathrm{CO}_{2}$ effects on biomass production and soil carbon in conventional and conservation cropping systems. Glob. Chang. Biol. 2005, 4, 657-665. [CrossRef]

13. Drennan, P.M.; Nobel, P.S. Responses of CAM species to increasing atmospheric $\mathrm{CO}_{2}$ concentration. Plant Cell Environ. 2000, 8, 767-781. [CrossRef]

14. Poorter, $\mathrm{H}$; Navas, M. Plant growth and competition at elevated $\mathrm{CO}_{2}$ : On winners, losers and functional groups. CO2 Biosph. 1993, 1, 77-97. [CrossRef]

15. Dong, J.L.; Gruda, N.; Lam, S.K.; Li, X.; Duan, Z.Q. Effects of elevated $\mathrm{CO}_{2}$ on nutritional quality of vegetables: A review. Front Plant Sci. 2018, 9, 924. [CrossRef] [PubMed]

16. Long, S.P.; Ainsworth, E.A.; Rogers, A.; Ort, D.R. Rising atmospheric carbon dioxide: Plants FACE the future. Annu. Rev. Biol. 2004, 55, 591-628. [CrossRef] [PubMed]

17. Yu, J.H.; Shu, Y.J.; Lv, J.F.; Zhang, G.B. Influences of low temperature and poor light on photosynthetic characteristics in eggplant seedlings. Acta Bot. Boreali Occident. Sin. 2004, 24, 831-836. 
18. Chen, E.Y. Grain Yield and Protein Quality in Response to Shading after Anthesis and Nitrogen Regulation in Wheat. Ph.D. Thesis, Shandong Agricultural University, Tai'an, China, 2012.

19. Qin, Y.; Zhang, H.; Dong, B.; Shi, C.; Li, Y.; Zhai, H.; Liu, M. Effects of elevated $\mathrm{CO}_{2}$ concentration on growth and water use efficiency of winter wheat under two soil water regimes. Agric. Water Manag. 2010, 97, 1742-1748.

20. Shirke, P.A.; Pathere, U.V. Diuranal and seasonal changes in photosynthesis and photosystem 2 photochemical efficiency in Prosopis juliflora leaves subjected to natural environmental stress. Photosynyhetica 2003, 41, 83-89. [CrossRef]

21. Farquhar, G.D.; Sharkey, T.D. Stomatal conductance and photosynthesis. Ann. Rev. 1982, 33, 317-345. [CrossRef]

22. Rajapake, N.C.; Pollock, R.K.; McMahon, M.J. Interpretation of light quality measurements and plant response in spectral filter research. HortScience 1992, 27, 1208-1211. [CrossRef]

23. Li, Q.; Kubota, C. Effects of supplemental light quality on growth and phytochemiclas of baby leaf lettuce. J. Envrion. Exp. Bot. 2009, 67, 59-64. [CrossRef]

24. Long, S.P.; Humphries, S.; Falkowski, P.G. Photoinhibition of photosynthesis in nature. Annu. Rev. Plant Physiol. Plant Mol. Biol. 1994, 45, 633-662. [CrossRef]

25. Steinger, T.; Roy, B.A.; Stanton, M.L. Evolution in stressful environments II: Adaptive value and costs of plasticity in response to low light in Sinapis arvensis. J. Evol. Biol. 2003, 16, 313-323. [CrossRef] [PubMed]

26. Farrar, J.E.; Jones, D.L. The control of carbon acquisition by roots. New Philol. 2000, 147, 43-53. [CrossRef]

27. Nager, K.A.; Schurr, U.; Walter, A. Dynamics of root growth stimulation in Nicotiana tabacum in increasing light intensity. Plant Cell Environ. 2006, 29, 1926-1945.

28. Olschowski, S.; Geiger, E.M.; Herrmann, J.V.; Sander, G.; Grüneberg, H. Effects of red, blue, and white LED irradiation on root and shoot development of Calibrachoa cuttings in comparison to high pressure sodium lamps. Acta Hortic. 2016, 1134, 245-250. [CrossRef]

29. Kitaya, Y.; Niu, G.; Kozai, T.; Ohashi, M. Photosynthetic photon flux, photoperiod, and $\mathrm{CO}_{2}$ concentration affect growth and morphology of lettuce plug seedling. HortScience 1998, 33, 58-62. [CrossRef]

30. Zheng, J.; He, D.; Ji, F. Effects of light intensity and photoperiod on runner plant propagation of hydroponic strawberry transplants under LED lighting. J. Agric. Biol. Eng. 2019, 12, 26-31. [CrossRef]

31. Xu, S.; Zhu, X.; Li, C.; Ye, Q. Effect of $\mathrm{CO}_{2}$ enrichment on photosynthesis and growth in Gerbera jamesonii. J. Sci. Hortic. 2014, 177, 77-84. [CrossRef]

32. Song, K.S.; Jeon, K.S.; Park Choi, K.S.; Kim, C.H.; Park, Y.B.; Kim, J.J. Characteristics of photosynthesis and leaf growth of Peucedanum japonicum by leaf mold and shading level in forest farming. Korean J. Med. Crop Sci. 2015, 23, 43-48. [CrossRef]

33. Croonenborghs, S.; Ceusters, J.; Londers, E.; De Proft, M.P. Effects of elevated $\mathrm{CO}_{2}$ on growth and morphological characteristics of ornamental bromeliads. Sci. Hortic. 2009, 2, 192-198. [CrossRef]

34. Qian, T.; Dieleman, J.A.; Elings, A.; Marcelis, L. Leaf photosynthetic and morphological responses to elevated $\mathrm{CO}_{2}$ concentration and altered fruit number in the semi-closed greenhouse. Sci. Hortic. 2012, 145, 1-9. [CrossRef]

35. Aranjuelo, I.; Cabrerizo, P.M.; Arrese-Igor, C.; Aparicio-Tejo, P.M. Pea plant responsiveness under elevated $\mathrm{CO}_{2}$ is conditioned by $\mathrm{N}$ source $\left(\mathrm{N}_{2}\right.$ fixation versus $\mathrm{NO}_{3}$-fertilization). Envirion. Exp. Bot. 2013, 95, 34-40. [CrossRef]

36. Tsukaya, H. Leaf shape: Genetic controls and environmental factors. Int. J. Dev. Biol. 2005, 49, 547-555. [CrossRef] [PubMed]

37. Utasi, L.; Monostori, I.; Végh, B.; Pék, Z.; Éva, D. Effects of light intensity and spectral composition on the growth and metabolism of spinach (Spinacia oleracea L.). Acta Biol. Plant. Agriensis 2019, 7, 3-18.

38. Feng, L.Y.; Raza, M.A.; Li, Z.C.; Chen, Y.K.; Khalid, M.H.B.; Du, J.B.; Liu, W.G.; Xu, X.L.; Song, C.; Yu, L.A.; et al. The influence of light intensity and leaf movement on photosynthesis characteristics and carbon balance of soybean. Front. Plant Sci. 2019, 9, 1952. [CrossRef]

39. Lee, H.B.; Lee, U.H.; An, S.K.; Park, J.H.; Kim, K.S. Growth characteristics and flowering initiation of Phalaenopsis Queen Beer 'Mantefon' as affected by the daily light integral. Hortic. Environ. Biotechnol. 2019, 60, 637-645. [CrossRef]

40. Pérez-López, U.; Sgherri, C.; Miranda-Apodaca, J.; Micaelli, F.; Lacuesta, M.; Mena-Petite, A.; Quartacci, M.F.; Muñoz-Rueda, A. Concentration of phenolic compounds is increased in lettuce grown under high light intensity and elevated $\mathrm{CO}_{2}$. Plant Physiol. Biochem 2018, 123, 233-241. 
41. Sgherri, C.; Scattino, C.; Pinzino, C.; Tonutti, P.; Ranieri, A.M. Ultarviolet-B radiation applied to detached peach fruit: A study of free radical generation by EPR spin trapping. Plant Physiol. Biochem. 2015, 96, 124-131. [CrossRef]

42. Wang, S.Y.; Bunce, J.A.; Mass, J.L. Elevated carbon dioxide increased content of antioxidant. J. Agric. Food Chem. 2003, 51, 4315-4320. [CrossRef]

43. Jaafar, H.Z.E.; Ibrahim, M.H.; Karimi, E. Phenolics and flavonoids compounds, phenylanine ammonia lyse and antioxidant activity responses to elevated $\mathrm{CO}_{2}$ in Labisia pumila (Myrisinaceae). Molecules 2012, 17, 6331-6347. [CrossRef]

44. Becker, C.; Kläring, H.P. $\mathrm{CO}_{2}$ enrichment can produce high red leaf lettuce yield while increasing most flavonoid glycoside and some caffeic acid derivative concentration. Food Chem. 2016, 199, 736-745. [CrossRef] [PubMed]

45. Kawasaki, S.I.; Toniaga, J.; Yabuta, S.; Wantanabe, K.; Jaiphong, T.; Ueno, M.; Kawamitsu, Y. Responses of growth, photosynthesis, and associated component to hypoxia at different light intensities in red leaf lettuce. Sci. Hortic. 2015, 193, 330-336. [CrossRef]

46. Hoagland, D.R.; Arnon, D.I. The Water-Culture Method for Growing Plants without Plant, 3rd ed.; University of California, College of Agriculture, Agricultural Experiment Station: Oakland, CA, USA, 1950.

47. Makker, H.P.S.; Becker, K. Nutrients and antiquality factors in different morphological parts of the Moringa oleifera tree. J. Agric. Sci. 1997, 128, 311-322. [CrossRef]

Publisher's Note: MDPI stays neutral with regard to jurisdictional claims in published maps and institutional affiliations. 